\title{
A Commentary on the Sphere of Neo-Liberalism and Youth
}

\author{
Jordan Kozuska
}

Neoliberalism's War on Higher Education works to unleash all of the underlying effects economic Darwinism has on the institution of higher education. It pushes the boundaries of rhetoric by discussing the relationship between political forces and the privatization of the system, how the economic aspect of neoliberalism is killing all chances that youth currently have in succeeding in this world [financially, socially, and politically], and it has dared to address the marginalization of people based on class, age, race, and sexual orientation (Giroux, 153). Lastly, Giroux addresses the effects of physical and rhetoric violence on/and within university institutions. The fact is that where our world is heading is not inevitable and that there is still a chance in changing the facets that this world is currently dependent upon. Giroux takes a stance arguing that higher education may be the bridge between the changes that need to happen and that it is possible that if we are to see any change in our world moving forward, chances are it will happen through the lens of university institutions due to it being the only place where some critical thought and ethics are still put into practice.

Even though the concept of critical thought is dwindling in these institutions due to external fear, it is still somewhat present in the classroom setting. Giroux says that reclaiming higher education as a democratic public sphere begins with the crucial project of challenging, among other things, those market fundamentalists, religious extremists, and rigid ideologues who harbor a deep disdain for critical thought and healthy skepticism, and who look with displeasure upon any form of education that teaches students to read the word and the world critically (142). The institution of higher education is a platform for change for today's youth because it is a stepping stone that represents hope for a greater future than what is available without a degree. It provides the opportunity to break through the part-time service sector that is so well known by young people as it is their current means to an end. Breaking through the neoliberal pedagogy is a daunting challenge as it is currently overtaking the world as we know it.

Giroux takes a stance in Neoliberalism's War on Higher Education in relation to students by stating that young people have been left out of the discourse of democracy. They are the new disposable individuals, a population lacking jobs, a decent education, and any hope of a future better than the one their parents inherited. They are a reminder of how finance capital has abandoned any viable vision of the future, including one that would support future generations 
(27). This is an invaluable statement that fully encompasses the route that our society is headed. Students are worth nothing more than the money they're paying to attend these privatized university institutions and it has gravely affected young people's mental health.

The alienation of young people is directly related to their mental health in numerous ways including the amount of debt accumulated by young people in order to attend higher education. According to the Canadian Federation of Students, by September of 2010 the amount of student loans owed to the Government of Canada surpassed fifteen billion dollars with the title of the article reading, "Education Shouldn't be a Debt Sentence" ("Student Debt in Canada"). It is well known how damaging the amount of debt young people have is, yet no one is willing to challenge the higher power and that is what Giroux's main argument is on this topic. The fear of the major corporations seems to outweigh the need to seek change.

Another facet of neoliberalism that directly affects the mental health and lifestyles of young people is the increase in service sector work. Service sector work is essentially the only type of work that is readily available to young people as it compliments youths' flexible lifestyles. However, this work is typically a dead-end job with no room to make their way up within in the company. It is a minimum wage position that helps to pay personal bills as they move through school. It sets young people back as they are more likely to live with their parents for an extended period of time as they transition into young adulthood. According to the 2011 Census of Population, it showed that $42.3 \%$ of young adults aged 20 to 29 live in the parental home. This is a massive change since 1981 as only $26.9 \%$ still lived with their parents throughout their twenties (Families, Households and Marital Status, 2011 Census of Population). This lack of independence is a critical aspect of a young person's life as in western culture, independence is a marker of adulthood. This part-time employment has made even more young people believe that they absolutely need a university education if they want to transition into a new role in life, and grow into being an adult. This is exactly what these large corporations want young people to think as they create a system to make them believe that they should always be chasing after something bigger and better, while spending more money in the process. Making the youth of today a consumer for life.

The economic Darwinism of the last thirty years has done more than throw the financial and credit systems into crisis; it has also waged an attack on all those social institutions that support critical modes of agency, reason, and meaningful dissent (Giroux, 151). This is directly relevant to university professors who have devoted their lives to the concept of critical thought and exploration. The privatization of higher education has gravely affected these individuals as they are now provided with the material that they are meant to teach. The classroom has evolved into a censored space that has no room for critical thought but rather focuses on the needs that serve those in the mass corporations above us. Claire Polster raised a discussion around the evolution of higher education as she said that higher education is neither natural nor inevitable: it is produced by people and can therefore be altered - even reversed - by them (Polster, 311). Essentially, she argues that we should not fear what is evolving because there is always the possibility of shifting the ways in which the institutions function.

On the contrary, Giroux holds firm that the censored content put in front of professors creates an array of distant fear that somewhat looms as professors stray into critical thought. Taken out of the context of deviance, Erving Goffman's later rendition of Lemert's Labelling Theory can be applied to teachers in the institution of university as he relates the social life to a theatre stating 
that we assume roles characterized by front stage and back stage selves. A deviant front stage role would show as a spoiled identity according to Goffman. These professors want to avoid spoiling their identities that they have worked their entire academic lives for and therefore they are more inclined to only teach the material that the privatized community believes in/supports. In this context, a front stage self would show as a professor teaching a lecture the way that it was designed, with the material provided in the textbook, in order to ensure that students are not getting carried away with any far-off ideas that are packed with critical analysis. A back-stage self in this context would be the professor's inner passion for learning and exploring deep/ critical ideas with a lecture hall full of enticed students who are all overwhelmed with concepts so far deep within their sociological imagination. This back-stage self is deviantized in the minds of the elite in charge of the institution as they strive for conformity and lack of retaliation from those serving within the institutions.

Giroux also argued that many students are so saddled with financial debt and focused on what it takes to get a job that they have little time for political activism (Giroux, 63). In more recent years this holds true. Students being saddled with debt and being overwhelmed with their lack of possibility does affect their mentality around voter participation. However, what Giroux failed to mention is that many young people don't even think that their vote will make a difference and they don't know enough about politics to feel that they are making an informed decision when casting their ballot. A question to consider is whether or not the umbrella of neoliberalism above us has anything to do with this or not. It is possible that they are trying to groom a generation to care less about politics and more about consumerism. In comparing the participation of voters of different age groups, according to Elections Canada, in the 2015 federal election about $57 \%$ of young people between the ages of 18-24 cast a vote and approximately 73\% of those between the ages of 55-64 years old voted ("Voter Turnout by Age Group"). This draws attention to the fact that young people are not voting the way that older generations and baby boomers are. This is not just because of young people not understanding the system on their own accord or feeling like their vote might not make a difference. This issue stems from the education system; from primary schooling through to higher education. The fear that Giroux spoke about professors feeling is directly relevant to politics. Politics is now seen as a taboo topic that could get professors in trouble if they speak about it as it is a very sensitive subject nowadays. We must ask ourselves why this is? Children are spending more and more time in the school system and this is where they are supposed to be educated on the world around them. However, this is not the case. The neoliberalism ideology has taken critical thought out of the classroom which makes it incredibly difficult to discuss topics such as politics as it is often seen as inappropriate. However, if we want to see a transition in the voting turnout of young people moving forward it will have to become a topic that is okay to be discussed openly and freely.

There are many topics in today's world that are not meant to be spoken about freely. In this course this semester there were many topics covered that were spoken about as "background concepts" and this is because that umbrella called neoliberalism covers these clouds that loom over us; these clouds being incredibly important topics that are left out of conversation due to the controversial nature of them. Giroux refers to this as manufactured ignorance. He says that manufactured ignorance is the new reigning mode of dystopian violence, spurred on by a marketdriven system that celebrates a passion for consumer goods over a passionate desire for community affairs, the well-being of others, and the principles of a democratic society (135). One major 
that was discussed in the background was climate change. Climate change is something that is freely discussed but the ignorance that Giroux referred to is in full force in relation to it. Ignorance combined with scientific thought destroys our ability to fully understand what is going on around us. At one point, we must consider the harm that we have already done to our planet rather than focusing solely on consuming goods. However, this is not what we are taught to do by the corporations above us. Our worldview as young consumers is controlled by those in the neoliberalist sphere.

Lastly, the sphere of neoliberalism also creates a massive divide between classes. Unapologetic in its implementation of austerity measures that cause massive amounts of human hardship and suffering, neoliberal capitalism consolidates class power on the backs of young people, workers, and others marginalized by class, race, and ethnicity (Giroux, 156). This divide in class and economic stability is prevalent in society today as the gap between the wealthy and poor is only increasing. If the gap continues to grow, it could be incredibly dangerous for those at the very top. According to conflict theory, deviance is directly related to social inequalities. It is said that the unequal distribution of wealth and power will eventually lead to conflict (J. Kozuska, personal communication, 18 August 2019). The social rules that control majority of the population are created by those in power, and work to serve their interests. This in turn deviantizes the interests and behaviors of the powerless and therefore they are more likely to break the rules that don't necessarily relate to their realities. The reason why this conflict theory has yet to implode on neoliberalism is due to the false consciousness that was created by those making the rules. The false consciousness is designed to make citizens believe that politics must be left up to the experts and it alienates us from understanding or believing in the true nature of our economic, political, and social realities. Those in power have citizens exactly where they want them: On the bottom, making the corporations money. In order to have any sort of shift moving forward, consumers will have to go beyond their role in society that was mapped out for them and practice their critical thought, delve into their sociological imagination, use democratic language and focus on creating new social movements. All of these things go against the false consciousness and it is exactly what needs to happen to overcome this tyranny reigning over us.

Overall, Henry Giroux's Neoliberalism's War on Higher Education is incredibly relevant to the material covered throughout this course. Giroux focused on the role that higher education plays in the realm of economic Darwinism as he says it is one of the last places where critical thought still exists. Higher education is where the change needs to originate from. Professors need to be powerful in their role as educators as they create analytical young adults and push the next generation to make a difference, standing up to neoliberalism and pushing past the false consciousness that is upon us now. 
Kozuska

\section{References}

Canadian Federation of Students. Student Debt in Canada: Education Shouldn't be a Debt Sentence 2015, cfs-fcee.ca/wp-content/uploads/2018/10/Factsheet-2015-05-Student-DebtEN.pdf. Accessed 16 Aug. 2019.

Giroux, Henry A., Neoliberalism's War on Higher Education, Toronto: Between the Lines, 2014.

"Living Arrangements of Young Adults Aged 20 to 29." Statistics Canada: Canada's National Statistical Agency, 23 July 2018, https://www12.statcan.gc.ca/censusrecensement/2011/as-sa/98-312-x/98-312-x2011003_3-eng.cfm.

"Private Interests at Public Expense: Transforming University Education in Canada" in Les Samuelson and Wayne Antony (eds.), Power and Resistance: Critical Thinking About Canadian Social Issues, 4th edition. Halifax: Fernwood Publishing, 2007.

"Voter Turnout by Age Group." Elections Canada Online| Voter Turnout by Age Group, 2 Aug. 1970,https://www.elections.ca/content.aspx?section=res\&dir=rec/eval/pes2015/vtsa\&doc ument=table1\&lang=e. 